\title{
A specific vaccine to protect patients with multiple sclerosis from herpes zoster
} Uma vacina específica para proteger os pacientes com esclerose múltipla do herpes zoster

Dear Editor,

Varicella zoster virus (VZV) infection and varicella vaccination induce VZV-specific antibody and T-cell-mediated immunity. When cell-mediated immunity declines, reactivation of VZV may lead to herpes zoster (HZ)1. Patients with multiple sclerosis (MS) starting new therapeutic regimens with potential immunosuppressive effect are supposed to be assessed for antibodies against VZV. If they have VZV-IgG antibodies, they can receive the medication and, if they do not, they are supposed to be vaccinated for VZV and receive the medication 4 to 6 weeks later. These patients are often starting new and/or more potent drugs, with a high risk of HZ. While being vaccinated and waiting for seroconversion (which may take months), the patient will not be able to start the more potent or newer medication.

In adults, two doses of vaccine are required to produce the same magnitude of response produced with one dose of vaccine in children ${ }^{2}$. This is a reflection of the natural decline with age in the ability of T-cells to recognize VZV antigens.

While the abovementioned strategy of one or two doses of VZV in seronegative patients with MS may seem adequate, protection against $\mathrm{HZ}$ depends upon vaccination of seropositive individuals as well. The ideal approach would be routine specific vaccination against HZ (Zostavax ${ }^{\circ}$ ) in all patients with MS at an early stage ${ }^{3}$. Thus, if the patient needs therapy escalation, the protection against $\mathrm{HZ}$ would already be in place. Many countries have programs for HZ prevention with $\mathrm{HZ}$ vaccine given to individuals over the age of 50 years, and a specific program to extend this program to patients with MS of all ages could be implemented. The costs involved in this vaccination may be relatively high, but the benefits of $\mathrm{HZ}$ vaccine for patients with MS cannot be underestimated. Both $\mathrm{HZ}^{4}$ and $\mathrm{MS}^{5}$ are associated to heavy socioeconomic burden.

Although HZ does not pose a fatal threat to most patients with MS, HZ vaccination could become routine for patients with MS. The systematic vaccination of individuals with altered immune function has already been suggested ${ }^{6}$ and should be considered when planning autoimmune disease management.

Yara Dadalti Fragoso, Joseph Bruno Bidin Brooks

\section{References}

\footnotetext{
1. Papaloukas O, Giannouli G, Papaevangelou V. Successes and challenges in varicella vaccine. Ther Adv Vaccines. 2014;2(2):39-55. http://dx.doi.org/10.1177/2051013613515621

2. Arvin AM, Greenberg HB. New viral vaccines. Virology. 2006;344(1):240-9. http://dx.doi.org/10.1016/j.virol.2005.09.057

3. Quan D, Cohrs RJ, Mahalingam R, Gilden DH. Prevention of shingles: safety and efficacy of live zoster vaccine. Ther Clin Risk Manag. 2007;3(4):633-9.

4. Panatto D, Bragazzi NL, Rizzitelli E, Bonanni P, Boccalini S, Icardi G, et al. Evaluation of the economic burden of Herpes
}

Zoster (HZ) infection. Hum Vaccin Immunother. 2014:e36160. http://dx.doi.org/10.4161/hv.36160

5. Jennum P, Wanscher B, Frederiksen J, Kjellberg J. The socioeconomic consequences of multiple sclerosis: a controlled national study. Eur Neuropsychopharmacol. 2012;22(1):36-43. http://dx.doi.org/10.1016/j.euroneuro.2011.05.001

6. Chen SY, Suaya JA, Li Q, Galindo CM, Misurski D, Burstin S, Levin MJ. Incidence of herpes zoster in patients with altered immune function. Infection. 2014;42(2):325-34. http://dx.doi.org/10.1007/s15010-013-0550-8

\footnotetext{
${ }^{1}$ Universidade Metropolitana de Santos, Departamento de Neurologia, Santos SP, Brazil.

Correspondence: Yara Dadalti Fragoso; Universidade Metropolitana de Santos, Departamento de Neurologia; Rua da Constituição, 374 ; $11015-470$ Santos SP, Brasil; E-mail:yara@bsnet.com.br

Conflict of interest: There is no conflict of interest to declare.

Received 23 January 2015; Accepted 12 February 2015.
} 